J. Egypt. Soc. Parasitol. (JESP), 50(1), 2020: 209 - 214

\title{
SCANNING ELECTRON MICROSCOPY OF CATATROPIS AEGYPTIACUS N. SP. (TREMATODA: NOTOCOTYLIDAE) FROM NORWAY BROWN RAT, RATTUS NORVEGICUS (MURIDAE: MAMMALIA) FROM EGYPT By
}

\author{
MOSTAFA M. RAMADAN, NAHED E. ABDOU, RANIA G. TAHA, \\ AND SAHAR H. HAROUN*
}

Department of Biological and Geological Sciences, Faculty of Education, Ain-Shams University, Cairo, Egypt ( ${ }^{*}$ Correspondence: saharharoun@yahoo.com)

\section{Abstract}

Catatropis aegyptiacus n. sp. was isolated from the large intestine of 28 out of 91 rat Rattus norvegicus. The prevalence of infection in males is $40 \%$ and $30 \%$ in females. The infection rate was $(54.54 \%, 36.84 \%, 26.3 \%$ and $23.8 \%)$ in winter, fall, summer and spring respectively. The study of the new species by light and scanning electron microscopy revealed that Catatropis aegyptiacus n. sp. can be distinguished from all other species of the genus in having 10-11 protruded ventral glands that extend from the intestinal bifurcation level to the ovarian level, the triangular pointed spines cover the first anterior third of the body, the position of the genital pore and larger egg size. Also, the outer rim of oral sucker has unciliated sensory papillae and the tegument of the anterior dorsal surface covered with irregular ridges studded randomly with unciliated and ciliated domed-like papillae. Tegument of the body posterior half has branching and anastomosing transverse striations with small unciliated sensory papillae.

Keywords: Egypt, Rattus norvegicus, Catatropis; Trematoda; Notocotylidae.

\section{Introduction}

Catatropis was first recorded by Frölich (1789) under the name of Fasciola verruco$s a$. Zeder (1800) transferred this worm to the genus Monostomum, then genus Catatropis was established (Odhner, 1905) to distinguish monostome digeneans with ventral structures of the 'verrucosa' type from those have 3 rows of ventral gland. Lühe (1909) created the family Notocotylidae to include three monostome genera; Notocotylus, genus have three lateral rows of ventral glands, Catatropis have two lateral row of ventral glands and a median ridge and Paramonostomum lacks ventral glands and ridges (Schuster and Wibbelt, 2012).

Catatropis Odhner, 1905 is a cosmopolitan species recorded worldwide; Europe, Africa, Asia, Venezuela, Russia, Japan, Australia, Canada, India, Argentina, Vietnam, Pakistan, Chile, Tunisia, Bangladesh, Oceania and America (Bayssade-Dufour et al, 1996; Koch, 2002; Flores and Brugni, 2006; Birmani et al,2011; Schuster and Wibbelt, 2012; Zaman et al, 2016; Izrailskaia et al, 2019).

Gupta and Jahan (1977) in India described C. rauschi from a spot-billed duck but did not recognize that the species name was preoccupied by Singh (1956). Thus, Gupta and Singh (1984) erected the name and gave C. poecylorhynchai for C. rauschi. In Pakistan, the same problem occurred with Schuster and Wibbelt (2012) who named the specimens from Northern shovelers, Anas clypeata as C. pakistanieses and did not aware that this name was occupied previously by Shafi et al. (1982) for the specimens of rice rat Bandicota bengalensis.

The genus Catatropis infects mainly birds especially geese, chicks, ducks and snails and rarely infects mammals; only C. morosovi and C. pakistanieses recorded from rodents (Shafi et al, 1982; Flores and Brugni, 2003; Barton and Blair, 2005).

In Egypt, a little information about $\mathrm{Ca}$ tatropis infecting Egyptian birds or mammals, until Yousif, et al. (2011) detected this genus as a first record in experimental infected host.

The present study aimed to describe a new Catatropis species by light and scanning electron microscopy isolated from Rattus norvegicus collected from Abu-Rawash and El-Mansuria Lake, Giza, Egypt. 


\section{Materials and Methods}

The specimens were collected from the large intestine of the wild rats Rattus norvegicus caught from Abu-Rawash and ElMansuria Lake in Giza, Egypt. Unstained trematodes were examined to describe the pattern and distribution of ventral glands, fixed under slight cover glass pressure in $70 \%$ ethyl alcohol, stained with acetic acid alum carmine, cleared in clove oil and finally mounted in Canada balsam. Diagrams were done by camera Lucida. All measurements were given in millimeter $(\mathrm{mm})$ and eggs in micrometer $(\mu \mathrm{m})$. Specimens were identified and compared with the available literature. Specimens (Holotype and Paratypes) were deposited in the helminthes Collection, Department of Biology, Faculty of Education, Ain Shams University, Cairo.

For SEM, some worms were fixed in $2 \%$ glutraldehyde in $0.1 \mathrm{M}$ sodium cacodylate buffer ( $\mathrm{pH}$ 7.2), washed three times in the same buffer, post fixed in osmium tetroxide $\left(\mathrm{O}_{\mathrm{S}} \mathrm{O}_{4}\right)$ for $2 \mathrm{hrs}$, washed in sodium cacodylate buffer, dehydrated in ascending ethanol series, and critical point dried (Abdou et al, 2001). Specimens were mounted on stubs and coated with gold examined and photographed with various magnifications under by Scanning Electron Microscope, Electron Microscopic Unit, the Atomic Energy Agency, Nasr City, Egypt.

\section{Results}

Catatropis aegyptiacus n. sp. was isolated from the large intestine of 28/91(30.76\%) Rattus norvegicus (Fig. 1:A, B, \& C). Prevalence in males was $40 \%$ \& $30 \%$ in females. Rate of infection varied seasonally, the highest rate was in winter $(54.54 \%)$ and the lowest was in spring $(23.8 \%)$, but infection rate fluctuated between $26.3 \%$ \& $36.84 \%$ in summer and fall respectively

Live specimens were pale yellow-orange to red. Body elongate, flattened dorso-ventrally, slightly pointed anteriorly and rounded posteriorly. Ventero-lateral glands arranged in 2 longitudinal lateral rows; each one with 10-11 glands. A median ventral glandu- lar ridge started from ovarian level to caecal bi-furcation anterior level. Spines covered body first third. Body was 2.38-3.12x0.91.2. Oral sucker terminal, measured 0.13 $0.15 \times 0.14-0.17$. Oesophagus thin, measures 0.07-0.19 in length. Intestinal caeca with irregular surface composed a special shape, passed between ovary and testes and terminated just before two testes end.

Testes elongated, highly lobulated, located laterally in body posterior part. Each one extended from vitellaria posterior portion to a very short distance from body extremity. Right testis measured 0.61-0.80x0.21-0.36, left testis measured 0.56-0.81x0.23-0.38.

Genital pore median, located posterior to oral sucker, measured 0.0285 in diameter. Cirrus pouch elongated, flask-shaped structure, measured $0.50-0.84 \times 0.10-0.64$. Cirrus pouch anterior oval part contained coiled vesicula seminalis.

Ovary lobed, located between testes, measured 0.19-0.40x0.17-0.24. Mehlis' gland rosette shaped, situated above ovary; measured $0.10-0.17 \times 0.14-0.25$. Vitellaria consisted of small branched follicles extended laterally approximately from body median part to testes anterior extremity, Length of right 0.59 1.14 , \& left one $0.66-0.96$. Uterus convoluted tubule extended between two intestinal caeca, with most proximal loop acted as a reseptaculum seminis. Eggs measured 30-40 $\mathrm{x} 20-38 \mu \mathrm{m}$. Each with two polar filaments; fully filament measured $70-130 \mu \mathrm{m}$. Uterus distal loops contained eggs without filaments, which started to appear through following loops obviously in proximal ones, Excretory bladder Y shaped.

SEM showed body leaf like (Fig. 2: A, B, C, D, E, F, G, H, I, \& J). Dorsal body surface with tegumental wrinkles; ventral one with 2 longitudinal rows of protruded spherical structures (ventral papillae or glands) ranged in number from 10 to 11 glands and occupied a considerable proportion of worm ventral surface. Confused papillae ridge in worm middle ventral surface. Ventral glands formed compact masses of secretory struc- 
tures opening on tegument outer surface evaginated or protruded to outside, Oral sucker tegumental surface unciliated sensory papillae, inner rim without papillae.

Body surface first anterior third ventrally covered with overlapped spines, directed backward, triangle in shape with pointed ends. Tegument of anterior body dorsal surface covered with irregular ridges. Unciliated and ciliated domed-like papillae scattered irregularly, Body tegument posterior half branched and anastomosing transverse striations with small unciliated sensory papillae.

\section{Taxonomy:}

Catatropis aegyptiacus n. sp.

Host: Rattus norvegicus Berkenhout, 1769

Site: large intestine

Locality: Nile Delta, Abu-Rawash and ElMansuria Lake, Giza Governorate, Egypt. Etymology: The specific name referred to Egypt, the type locality.

\section{Discussion}

Odhner (1905) described genus Catatropis for the first time from anseriformes collected from Sweden. Genus distinguished from Notocotylus Diesing, 1839 (Famliy: Notocotylidae) in having a median ventral ridge and everted two lateral rows of ventral glands or papaillae while Notocotylus genus have 3 rows of ventral glands without median ridge. Ventral glands arrangement was of generic diagnosis as well as, their number and the genital pore position (Mackinnon, 1982).

Schuster and Wibbelt (2012) reported that genus Catatropis included 17 species and 3 species were added by Izrailskaia et al. (2019). So, the genus Catatropis included 20 valid species, and the present Catatropis aegyptiacus is new species.

In the present $C$. aegyptiacus, genital pore was situated directly posterior to oral sucker as in C. indicus, C. pricei, C. harwoodi, C. chinensis, C. misrai, C. poecyclorhynchai, C. pakistane- nsis and C. vietnamensis. But, in all other Catatropis species the genital pore opens just posteriorly to the intestinal caeca bifurcation. In the present $C$. aegyptiacus, number of ventral papillae in each lateral row was 10-11. This distinguished $C$. aegyptiacus from $C$. orientalis, C. harwoodi, C. poecylorhynchai, C. joyeuxi, C. lagunae and $C$. vietnamensis having up to 9 ventral papillae and from $C$. verrucosa, $C$. liara, $C$. indicus, C. cygni, C. morosovi, C. chinensis and $C$. misrai having more than 12 ventral papillae.

The present $C$. aegyptiacus was nearly close to $C$. pakistanensis with 9-10 ventral glands, but disagreed in the tegumental spicules pattern where in C. pakistanensis spines cover all ventral surface and dorsal surface anterior half, while in C. aegyptiacus spines cover only the worm first third of ventral surface. Also, the present C. aegyptiacus disagreed with $C$. vietnamensis whose scalelike spines covered the ventral surface anterior half and extension of ventral ridge to the internal seminal vesicle level to the ovary of end. Moreover, the present C. aegyptiacus differed from $C$. indicus and C. misrai in the absence of tegumental spines. The C. aegyptiacus testes were lobed but entire in $C$. pricei. However, the present $C$. aegyptiacus was in harmony with $C$. pakistanieses, in the cuticular spines distribution in the first third of the body but differed in the ventral glands number and genital pore position, as in $C$. pakistanieses, the number of ventral glands was 12 and genital pore was posterior to intestinal bifurcation.

On the other hand, ventral papillae number in each row was more or less similar with $C$. hatcheri (10-12) and C. chilinae (9-11), but disagreed with both in the genital pore position and eggs in C. chilinae have one or two filaments at one pole, while the eggs in $C$. aegyptiacus have one filaments at each pole.

In the present $C$. aegyptiacus, eggs were $(30-40 \times 20-38 \mu \mathrm{m})$, larger than in $C$. hatcheri $(22-24 \times 11-13 \mu \mathrm{m})$, C. liara $(18 \times 10 \mu \mathrm{m})$, C. charadrii $(18 \times 14 \mu \mathrm{m})$, C. cygni $(19-21$ $\times 12-14 \mu \mathrm{m}), C$. indicus $(17-20 \times 8-10 \mu \mathrm{m}), C$. pricei $(17-20 \times 10-11 \mu \mathrm{m}), C$. harwodii $(18 \times$ $11 \mu \mathrm{m})$, C. lagunae $(20 \times 10 \mu \mathrm{m})$ C. orientalis (24-26 $\mu \mathrm{m})$, C. morosovi $(25-29 \mu \mathrm{m})$, C. chilinae $(24-29 \times 12-14) \&$ C. verrucosa $(25-30)$ 
after (Flores and Brugni, 2003; 2006).

The ornamentations of sensory papillae, spines, folds, pits, grooves and various shapes of ridges were of tegument of trematode general characters (Schmidt and Roberts, 2000). In the present $C$. aegypticus, the first anterior third of was covered with triangular pointed spines as those in other flukes as Anchitrema sangiuneum and Prosthodendrium prosthodendrium urna (Ammar et al, 2003), Acanthotrema felis (Sohn et al, 2003) and Stictodora fuscatum (Abdul-Salam et al, 2000). These spines are used for abrasion of the intestinal host for feeding and anchorage.

In the $C$. aegypticus, oral sucker rim was devoid of tegumental spines as in Macroorchis spinulosus (Hong et al, 2004) and Leucochloridium sp. (Bakke, 1976). The latter author suggested that the absence of spines on the suckers' rim indicated the necessity for a smooth seal against the host mucosa. But, the oral sucker outer rim has unciliated sensory papillae. This agreed with Catatropis indicus and Allogenarchopsis bareilliensis, where papillae played important role in the feeding (Lee et al, 1987) and sucking as well as acted as tango-rheo-or mechanoreceptive (Gupta et al, 2017)

The present $C$. aegyptiacus was distinguished by ventral glands that secreted proteolytic enzymes (Harwood, 1939). Martin (1956) found that the median ventral ridge was formed of unicellular glands for adhesion in host caecal mucosa. The present $C$. aegypticus has a high number of sensory papillae on the tegumental body posterior part, which played an important role in the fluke physiological and metabolic functions (Sohn et al, 2003). The dorsal body tegumental wrinkles surface was similar to the Allogenarchopsis tegument encircled by tegu- mental folds or ridges causing body flexure and oral sucker movement (Abdou et al, 2001). Tegumentary ridges caused by contraction waves of the fluke internal musculature (Otubanjo, 1985).

\section{Conclusion}

Catatropis aegyptiacus has the following features: ventral glands (10-11) extend from the intestinal bifurcation level to ovarian level and the spines cover the first body anterior third, the genital pore position and larger egg size recommended C. aegyptiacus as new Egyptian species and new host record.

\section{References}

Abdou, NE, Heckmann, RA, Beltagy, SM, Ashour, AA, 2001: Pseudoplagioporus interruptus Durio and Manter, 1968 and Hamacreadium agyptia (Trematoda: Opecoeliidae) from the Red Sea Fish in Egypt. J. King Abdulaziz Univ (Mar Sci) Spec Issue 12:175-88.

Abdel-Salam, A, Nair, SB, Ashkanani, H, 2000: Surface ultrastructure of Sticodora fuscatum (Tre-matoda: Heterophyidae) from Kuwait Bay. Parasitol. 24: 1-8.

Ammar, KNA, Mostafa, OMS, Taha, HA, 2003: Surface topography of adult Anchitrema sanguineum (Sansio, 1894) Looss, 1899 and Prosthodendrium (Prosthodendrium) urna (Looss, 1907) Doll-fus, 1931 infecting bats in Upper Egypt (Qena). J. Egypt. Soc. Parasitol. 33, 3:67986.

Bakke, A, 1976: Functional morphology and surface topography of Leucochloridium sp. (Digenea) revealed by scanning electron microscope. Z. Parasitenk. 51:115-28.

Barton, DP, Blair, D, 2005: Family Notocotylidae. In: Jones A, Bray RA, Gibson DI (eds.) Keys to the trematodes, vol 2. Biddles Ltd., King's Lynn, London.

Bayssade-Dufour, C, Albaret, JL, FermetQuinet, H, Farhati, K, 1996: Catatropis lagunae n. sp., Trematoda, Notocotylidae, parasite d'oiseaux de mer. Cana. Field-Naturalist 110: 392-402

Birmani, NA, Dharejo, AM, Khan, MM, 2011: Catatropis sp. (trematoda: notocotylidae) from the black coot, fulica atra linnaeus, 1758 (Gruiformes: Rallidae) in Sindh Province of Pakistan. J. Anim. Plant Sci. 21, 4:872-83.

Flores, V, Brugni, N, 2003: Catatropis chilinae n. sp. (Digenea: Notocotylidae) from Chilina dombeiana (Gastropoda: Pulmonata) and notes on its life-cycle in Patagonia, Argentina. Syst. Parasitol. 54: 89-96. 
Flores, V, Brugni, N, 2006: Catatropis hatchery n. sp. (Digenea: Notocotylidae) from Heleobia hat-cheri (Prosobranchia: Hydrobiidae) and notes on its live-cycle in Patagonia, Argentina. Syst. Parasitol. 63:109-16

Gupta, N, Gupta, DK, Urabe, M, 2017: Taxonomic tools for the identification of Allogenarchopsis bareilliensis n. sp. (Digenea: Hemiuroidea: Derogenidae) from Channa striata of Rohilkhand, India based on light and scanning electron microscopic studies. J. Parasitol. Dis. 41, 1:29-39.

Gupta, V, Jahan, A, 1977: Some trematodes from avian hosts of India. Ann. Inst. Biol. Univ. Nat. Mexico, 48:13-26

Gupta, PC, Sing, RB, 1984: On two species of the genus Catatropis Odhner, 1905 (Digenea: Notocotylidae) from Asian hosts in India. Ind. J. Helminthol. 35:122-8.

Harwood, PD, 1939: Notes on Tennessee helminths: IV- North American trematodes of the subfamily Notocotylinae. J. Tenn Acad. Sci., 14, 332-340.

Hong, S, Woo, H, Kwon, OS, 2004: Developmental surface ultrastructure of Macroorchis spinulosus in albino rats. Korean Parasitol. 42, 4: 151-7.

Izrailskaia1, AV, Besprozvannykh, VV, Tatonova, YV, Nguyen, HM, Ngo, HD, 2019: Developm-ental stages of Notocotylus magniovatus Yamaguti, 1934, Catatropis vietnamensis n. sp., Pseudoca-tatropis dvoryadkini n. sp., and phylogenetic relationships of Notocotylidae Lühe, 1909. Parasitol. Res. 118:469-81

Koch, M, 2002: First record and description of Catatropis indicus Srivastava, 1935 (Digenea: Notocotylidae), in Australia. Memoirs of the Queensland Museum 48:147-53.

Lee, SH, Seo, BS, Chai, JY, Hong, SJ, Jun, HS, et al, 1987: Scanning electron microscopical findings of Echinochasmus japonicus tegument. Korean J. Parasitol. 25:51-8.

Mackinnon, BM, 1982: The development of the ventral papillae of Notocotylus triserialis (Digenea: Notocotylidae). Z. Parasitenkd. 68, 3: 279-93.

Martin, WE, 1956: Life cycle of Catatropis johnstoni $\mathrm{n}$. sp. (Trematoda: Notocotylidae). Trans. Am. Microsc. Soc. 75, 1:117-28

Odhner, T, 1905: Die Trematoden des arktischen Gebietes: Inaugural-Dissertation, University Ups-ala.

Otubanjo, OA, 1985: Scanning electron microscopic studies of the body surface and external genitalia of a dicrocoeliid trematode, Concinnum epomopis ,Sandground 1973. Zeitschrift fur Parasiten-kunde 71:495-504

Schmidt, G, Roberts, L, 2000: Foundations of Parasitology, $6^{\text {th }}$ Edn. Mcraw-Hill, New York

Schuster, RK, Wibbelt, G, 2012: Catatropis pakistanensis n. sp.(Trematoda: Notocotylidae) from northern shovelers, Anas clypeata (Anatidae: Aves) from Pakistan with some remarks on the history of Catatropis species. Helminthologia 49, 1:43-8.

Shafi, MM, Rehana, R, Samad, K, 1982: Catatropis pakistanensis, Notocotylidae: A new species from new host, rice rat (Bandicota bengalensis) in Pakistan. Pakis. J. Agric. Res. 3, 1: 34-9.

Singh, KS, 1956: Catatropis rauschi sp. nov. (Notocotylidae) from the pintail Dafila acuta from India. J. Zool. Soc. India 8: 43-6

Sohn, WM, Han, ET, Chai, JY, 2003: Acanthotrema felis n. sp. (Digenea: Heterophyidae). Korean J. Elec. Micro. 30:205-12.

Yousif, F, El Bardicy, S, Tadros, M, Ayoub, M, 2011: First Record of Catatropis indicus Srivastava (Notocotylidae) from Gabbiella senaariensis Küster (Bithyniidae) in Egypt. Austral. J. Basic Appl. Sci. 5, 9:724-8.

Zaman, RF, Khatun, A, Alam, S, Muznebin, F, Khanum, H, 2016: Comparative incidence of helminth parasites in domestic fowl, white leg horne, layer and cock. Bangladesh J. Zool. 44, 2:245-54.

\section{Explanation of figures}

Fig. 1: Light Microscope Drawing of Catatropis aegyptiacus n.sp. A- Adult worms (I, intestine; Cp, cirrus pouch; T, testis; ov, ovary; u, uterus; M, Mehlis gland; vg, vitelline gland; Ex, excretory pore) B-Terminal genitalia (os, oral sucker; Ga, genital atrium; Go, genital opening); C-Eggs.

Figs. 2: Scanning Electron Micrographs of Catatropis aegyptiacus n.sp.: A: Dorsal view of Catatropis aegyptiacus sp. n. showed tegumental wrinkles and oral sucker (Os). Bar $=100 \mu \mathrm{m}$. B: Ventral surface of the worm showing the ventral glands (Vg). Bar=50 $\mu \mathrm{m}$. C: Posterior part of the ventral surface of fluke showed protruded ventral glands $(\mathrm{Vg})$. Bar $=50 \mu \mathrm{m}$. D: High magnification of oral sucker show showed outer rim with unciliated sensory papillae (Arrows). Bar $=10 \mu \mathrm{m}$. E: Top view of oral sucker (Os) showed mouth opening (Mo) with smooth tegument around it. Bar $=10 \mu \mathrm{m}$. F: High magnification of anterior ventral tegumental body surface showed spines (S). Bar=5 $\mu \mathrm{m}$. G: High magnification of the anterior dorsal tegumental body surface showed irregular ridges. Bar $=10 \mu \mathrm{m}$. H: Enlarged view of ciliated and unciliated domed papillae (Astons) and tegumental minute structures (Arrows). Bar $=1 \mu \mathrm{m}$. I: A high magnification of posterior tegumental body surface showed longitudinal striations. Bar $=10 \mu \mathrm{m}$. J: Enlarged view of the posterior tegumental body surface showed distributed unciliated small sensory papillae (Astons). Bar $=5 \mu \mathrm{m}$ 


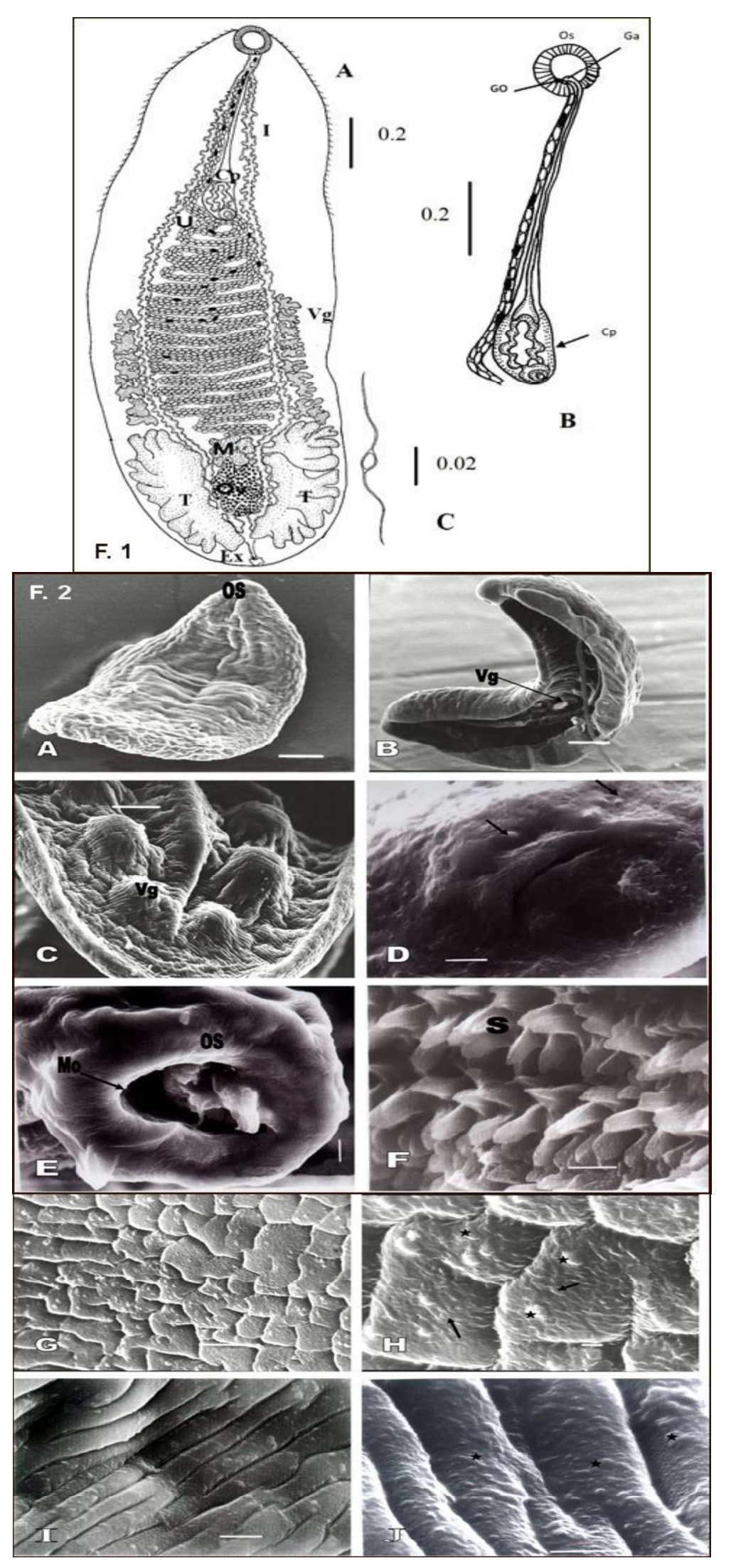

